\title{
CAN ANY RIGHT OF DIRECT CITATION BE GIVEN TO A STATE IN INTERNA- TIONAL CONFLICTS?
}

By direct action we must understand the power of an injured party to make its appeal personally to competent jurisdiction, without being obliged to seek either the intervention of a constituted authority or a preliminary authorization, or even an understanding with its adversary.

In private law the general rule is that there is, for every individual, free access to the courts. It is only in exceptional cases, and because of considerations of public peace, that certain suits are subordinated to the consent of the government or reserved to its initiative.

In international law, on the other hand, the possibility has never been conceived, up to now, of a judgment of court except after an agreement by which all the parties in litigation have agreed to accept this procedure. Since the idea of arbitration preceded and still dominates the idea of justice in the minds of the best theorists, they are constrained by a knowledge, slightly too technical, of the principles which rule the verbal process of compromise. Article 1006 of the French Code of Civil Procedure provides in this respect that "the compromise shall designate the points in litigation and the names of the arbitrators, on penalty of being null and void." This rule is well understood in the case of private law, and it is its transposition into international law which allows some criticism. Since there exist for individuals tribunals of common law with recognized plenary jurisdiction, it is natural if not to suspect, at least to consider as abnormal, the attitude of those parties in the suit who agree to carry before a third party a litigation, the cognizance of which ought to appertain to the established power, and it is natural, also, not to treat this agreement as a regular course of procedure unless the agreement and wishes of the parties are really manifested in the conditions demanded by Article roo6, cited above, or by similar provisions which exist in other systems of legislation.

But when it is sought to adapt this principle to international law it must be reasoned out by a slightly stricter method. There must be one of two situations. Either it is planned to make the court established at the Hague a regular and permanent jurisdiction, and 
then it must base its procedure upon the rules of the common law and not upon the exceptional rules of particular cases of arbitration; or one must be content in the future as in the past, with the purely arbitrary procedure, in which case it was superfluous to create an authoritative and perpetual organism. Before 1899 , this inconsistency did not exist. There was no international body designed to separate the states, and formerly it was perfectly evident that no arbitration could be produced unless the parties had first placed themselves in accord upon the object of the litigation and upon the choice of their judges. But as sooz as the regular court is established, this court should be a tribunal in the strictest acceptation of the term and access to it should be open to everybody interested. We can explain, then, only with great difficulty, Article $3 I$ of the first Hague Convention, No. 52 of the Convention of 1907 , which appoints that the powers which resort to arbitration shall sign a special agreement in which are clearly set out the causes of the litigation, as well as the exterit of the powers of the arbitrators . . . etc. It is, then, impossible for a state to summon or even to drag its adversary before the established jurisdiction, if the adversary is unwilling to follow voluntarily, and if it has not consented to sign for this purpose a preliminary agreement. Nevertheless, the Conference of 1899 should be congratulated in that it rejected upon the urgency of M. Asser a supplementary rule contained in Article 2 of the advance project as issued by Russia, which would have provided that all matters of fact and of law implicated in the litigation submitted to the arbitrators should be specified as a preliminary agreement. If this condition had been insisted upon, it would have become almost impossible for states, whose relations had become seriously strained, to succeed in agreeing, by the mere result of a diplomatic negotiation, upon the terms of an agreement so minute; and one would have given a very true argument to the skepticism of those who contend that arbitration cannot result between any except those who have decided in advance to reach an agreement. That is precisely what happened when the Madeira affair arose. The Portuguese government proposed to appeal to the arbitration of the Hague Tribunal and the German government opposed such a settlement. That is good proof of the inefficacy of a preliminary agreement.

Such inconvenience cannot be avoided except by allowing a state always to cite directly its adversary before the Hague Tribunal and to demand against the latter a judgment by default if it does not present itself. The progress of law has tended, from the very beginning, to make it possible for the courts to decide in the absence 
of a party as practically and as equitably as in his presence, and private law has not escaped the successive phases of this evolution which will be imposed upon public law. Roman History shows that in the early times the personal appearance of the parties was indispensable to give the magistrate power to settle their difficulties. When the plaintiff was not able to make his adversary answer the summons, he took him by the throat and carried him to court by force, "obtorto collo," as the books say. Then, since no violence could be committed in the enclosure of justice, he let go his hold and apostrophized the defendant in these terms, "Quod te forte invenio." And it was only in this way that the case could be litigated. To-day civil procedure is happily freed from the necessity of such a clumsy subterfuge. It has been long admitted not only that the parties can be brought together by mandate, but that, in the absence of an appearance, competent jurisdiction is validly taken by a process of summoning, specifying the matter in suit and containing an adjournment for the defendant up to the expiration of the time set by law. Let international procedure accomplish the same progress and let a diplomatic summons alone allow the plaintiff to supply a hearing to his adversary before the Hague Tribunal, whose jurisdiction will rise by this single act.

This proposal runs the risk of meeting an objection in theory from those who will make it a point to suggest that no one of the authors who have treated up to this time the question of international arbitration, has foreseen the possibility of litigating an international case otherwise than by a preliminary compromise between the parties. Not only MM. Kamarowski, ${ }^{1}$ Goldschmidt; ${ }^{2}$ Bluntschli, ${ }^{3}$ Mérignhac,, Michel Revon, ${ }^{5}$ Ferdinand Dreyfus, ${ }^{6}$ and many others have proposed no enlargement of the traditional procedure in this respect, but even Mr. Dudley Field, the best author of a project for international codification, ${ }^{7}$ has sanctioned the old errors. The excuse for all these authors is that their works were all prior to the first Hague Conference, and that, while no permanent Tribunal existed, and while it was necessary in each case to have recourse to arbitrators for that case alone, necessity

\footnotetext{
I. Le Tribunal International, pp. 502, seq.

2. Revue de Droit International, 1874-75, p. 227.

3. Droit International codifie, Art. 492, bis.

4. Traité theorique et pratique de l'Arbitrage International, pp. 502

5. L'Arbitrage International, p. 518.

6. L'Arbitrage International, p. 295.

7. A High Tribunal of Arbitration, Art. 534, 535 .
} seg. 
demanded a preliminary compromise before any judicial action could be taken. To-day the situation has changed and the system of introducing cases should be applied with better results. In a more enlightened age there should be a procedure correspondingly more perfect. That is why we adopt very gladly the resolution which was taken first at Lisle by the Third National Congress of French Societies of Peace in April, I905, upon the suggestion of M. Lucien LeFoyer. This resolution is worded thus: ${ }^{8}$

"Since the Congress believes that arbitration cannot be actually obligatory unless the general agreement made by the contracting powers results in an effective arbitration in all those individual difficulties which cannot be settled by amicable means, we suggest that the Second Hague Conference constitute the right of summoning one power by another, that it rule the procedure by the system of default and that it originate a common organization, acting spontaneously in cases which are marked out, in the name and in the interest of what the first Hague Convention called the "Society of Civilized Nations."

Supposing that this law of direct citation, so sanctioned by the vote of a national congress, be admitted in principle, its execution will evidently carry with it some difficulties as is the case in the application of all the best reforms. But none of these difficulties will be insurmountable.

First, it is to be feared just as the resolution above quoted foresaw, that the right of direct citation often can end only in a judgment by default. This would be unfortunate, but is nevertheless not to be avoided. A nation suspected of not being willing to subject itself to an agreement for arbitration will subject itself still less to arbitration itself, and, entrenching itself behind the fiction of its sovereignty, it will sometimes brave the decision which interferes with it, rather than provide for it by the means of regular opposition. It is then that means of execution will be inevitable. Refusal by a state to answer the summons of its adversary will be so much the more regrettable in that the duty of the judge in international law, as well as in internal law, is not only to decide, but also to conciliate, and conciliation is only possible when all parties are present. Such a nation stands the chance then, by the existence of a procedure by default, of finding itself judged, when, by appearing voluntarily, it might have heard the arguments of its adversary, have recognized all or part of its wrong-doings, have heard the counsel of the Tribunal and have submitted, perhaps, to a settlement satis-

8. See Revue de la Paix, May-June No., I905, p. 173. 
factory to its pride, as well as to its material interests. In place of this, obstinacy on the part of the defendant leaves it no choice except between shameful submission or armed resistance. This is all true, but the force, even, of these objections, has the result of hurting the party summoned, who has, more than anybody, an interest in hindering such results. It is this party, in fine, which should find it of the greatest advantage to have a good arrangement rather than disadvantageous trial, and to try conciliation before the rendition of judgment. It is preferable that its arguments, its evidence and its rights, instead of remaining hidden beneath the veil of its silence, or behind its obstinacy, should be loudly proclaimed, pressed, sustained and defended at the bar of the International Tribunal. When one has good reasons, one is always ready to show them, and if one avoids discussion, he is easily convinced that everybody will consider him in the wrong. Besides, is it not certain that the parties summoned, far from avoiding discussion, will be desirous, in most cases, of pleading and of throwing out to the whole world the cry, more or less personal, of its ambitions and of its sincerity? Allowing default may be the attitude of those sovereigns who feel that their cause is lost in advance, not only in the minds of the jurists, but also from the standpoint of public opinion; one can imagine easily enough that the Sultan would default rather than render an account of the Armenian massacre, and the Czar would have had, perhaps, the same hesitation in replying to a summons by Finland. But then, in cases of this nature, where there is a true unanimity of opinion throughout the world, is it not evident that the pressure of the universal conscience in favor of a judgment by default will be so powerful that it will be impossible for the party condernned, even by its arms, to brave this moral opposition? The sentence would certainly be executed and then international arbitration would have consummated its greatest triumph and proven its entire efficacy, since it would have broken, by the sole power of law, the most obstinate resistance, or the most unconquerable inertia. We see, then, that the principal inconvenience of the right of direct citation will neutralize and eliminate itself.

The exercise of a direct citation will demand an additional rule in order to determine what the composition of the arbitration commission shall be. In the case of the first Hague Convention, the arbitrators were designated by a common agreement of the parties acting in the preliminary agreement. ${ }^{9}$ As soon as there is a direct citation without preliminary agreement, one cannot see immediately who will

9. Art. 32; now Art. 55 (1907). 
do the judging, unless the permanent court proposed, but not yet voted for by the second Hague Conference, be finally admitted, in which case, according to Articles I7, I8 and I9 of the proposal, such a court might be always competent. If not it is evident that while the act of summoning will make the whole court take jurisdiction, it cannot be expected that all the members of this court can be compelled to participate in the judgment, and since, on the other hand, the selection by agreement remains impossible if the party prosecuted allows default, we are reduced to the one solution of selecting by lot the arbitrators of the case. This selection would be made by the permanent bureau, which will serve on record at the Court of the Hague. It may be noticed that the Convention of 1907 already admits the selection by lot of the Umpire (Article 45 in fine, and Article 87). The solution would have, moreover, some advantages, notably that of protecting the arbitrators against the suspicion of partiality which always falls upon arbitrators chosen by the parties themselves. It is plain that in this case the arbitrators of both parties should be drawn by lot, and that the state prosecuting should not be able to take advantage of its initiative by having arbitrators of its choice, whose decision would have still less authority against the state which was being sued. Nevertheless, the defendant could be allowed after an attempt had been made to persuade it to present itself even tardily, and make its voluntary appearance in the time between the summons and the judgment-or even after the default had been pronounced, in the interval between judgment by default and the time allowed for protest-which should re-establish for both parties the means to choose their arbitrators after the common law of Article 32, now Article 55, (1907). A remarkable advance towards such a state of international law has been made in 1907 by the new Articles, 48, Section 3 , and 53 of the second Hague Convention. These articles provide that any state may directly send over to the international bureau at the Hague a declaration stating that it is willing to submit its case to arbitration, and the bureau is then obliged to give immediate knowledge of this declaration to the other power. The necessity of a special agreement is not avoided, but the agreement, instead of being settled by diplomatic intercourse, may be settled by the bureat itself, on a single appeal of one of the powers, in two cases: (I) When the cause of the conflict has been foreseen by a previous treaty of arbitration. (2) When it arises from one of those foreign loans for which General Porter's proposition has provided that they must always be settled by arbitration.

But there is another difficulty. To whom shall the right of cita- 
tion be allowed? Shall it belong as well to subject states as to those which are sovereign? Shall it appertain to former as well as to existent states; to decayed nations reduced to a condition of humble international vassalage, as well as to people who, independent and proud, have preserved a political identity and are able to speak in their own name? Shall it belong to Poland, to Alsace-Lorraine, to Ireland, to the Jewish people? Shall it belong to the Pope, struggling against the violation of a concordat? Shall it belong to a negro tribe, nameless or effaced, throwing out a scarcely audible cry of woe against an oppressing state? It is here that the politic spirit, which prevailed in both Hague Conferences, should be tempered by the spirit of equity. At first sight such questions demand only one answer, that of non-reception. There is no solution more seductive for all those who flatter themselves that they have some practical sense. It needs no effort of the imagination, gives an answer to everything and is never compromising to him who adopts it. But a desire for analysis vexes the philosopher; a breath of love transports the philanthropist; a sentiment of equity permeates the jurist and finally, under this triple inspiration, a passion for justice, capable of conquering all obstacles, takes possession of the popular mind, which, in its turn, rules the politician. It is necessary, then, to reflect in spite of ourselves, and we will not elude, in the end, the imperious question, "Who are the persons of international law to whom the power of summoning should appertain?"

Let us take immediately the side of the general disposition and of political necessities. Since the jurisdiction of the Hague is international in character, it is evident that no question of domestic politics can be conferred upon it, and that there can be no action by Brittany or Savoy against the French Government; no more, moreover, can there be a claim by the Canton of Neufchâtel against the Swiss Republic, or of the city of London against the king of England. Administration problems which can be raised between different governments and the geographical portion of their domains remain in the exclusive jurisdiction of national tribunals. Certain though this principle is, it remains none the less difficult, in many cases, to trace a precise boundary between ethnographic unities which enjoy political personality, and those which are only dependencies of another sovereignty. The acuteness of this question is even more important because often the people, whose autonomy is the more doubtful, raise problems, the international character of which is most apparent. It is thus that the question of Alsace-Lorraine, which has been cited for thirty-seven years as the most troublesome type of international questions, arises from a situation of two provinces which, in 
fact, and even in law, after the traditional theory of conquest, have passed beneath the rule of the German Government, and whose autonomy is not to be contended for, since even before the treaty of Frankfort they were dependent upon the French Government, so that their international personality is not easy to determine. Shall, or shall not, the doctrine of the pacificator extend so far as to allow them a right of direct citation? When it was asked if the affair of the Transvaal could not be submitted to the Hague Tribunal, England objected that it had to do, in her opinion, with a question of domestic politics. This point of view was very questionable. It was contrary, indeed, to the evidence. But, supposing that it had been well taken, the difference arising between the metropolis and a people which it considered as a colonial possession, would have had none the less all the characteristics of an international litigation of the first degree. It is necessary, then, to grasp the question very closely in order to find a satisfactory solution.

Logic demands, first of all, one distinction. It is necessary to understand clearly the difference between the right of citation and the object of the citation, that is to say, the power of demanding the jurisdiction of the Hague Tribunal on the one hand and the conditions upon which this jurisdiction may be demanded on the other. It is, indeed, evident that a question may be and may remain one of international order, even though it arises from the condition of a people, a province or a principality, to which the right of citation does not appertain; and one is led by this observation to admit that the power to cite may be denied to such and such a party injured without making it impossible to submit its cause to the Hague Tribunal whenever there arises a question of international law, however little the case was originally capable of being brought up by another party which later has an actual interest in the outcome and which possesses the requisite qualities to demand jurisdiction.

We see, then, that it is easy to limit strictly, without fear of any resulting injustice, the power of citation and to admit the application of a principle consistent with the terms of which there can be no action except for those who constitute a physical or moral personage, that is to say, for sovereign powers, independent and autonomous. We can give the right of citation to tributary states and even to states submitting to a protectorate, because, in spite of their bonds of vassalage, their personality remains whole and their dependency does not constitute a confederation. But one is not able to demand the same right for parties of a constituted state nor of ancient states actually absorbed in another state, or in a confederation. Indeed, to the extent that such parties are in conflict with 
their own governments, the question would be only a matter of domestic politics; if they find themselves in controversy with another state, it is not personally, but by the sole organism of their governments that their cause may be upheld. Even in the United States, where each one of the members of the Union enjoys a domestic government comparatively autonomous, it is provided in the terms of the Constitution ${ }^{10}$ that local administrations may not entertain any relationship with a foreigner and that foreign politics are for the exclusive administration of a federal cabinet which sits at Washington. The case was the same for the Scandinavian Federation until its recent dissolution; and if the Norwegian Cabinet has been able to obtain, by reason of its secession, an independence, implying the right to cite in future, which we had formerly denied, this could only arise at the moment when the controversy arising between Sweden and Norway had transformed into questions of foreign politics questions which up to that time related only to domestic politics. The same reasoning leads us to believe equally that the German states and the Swiss cantons respectively absorbed in the confederations, having the power to represent them in the outer world, would not be able to pretend to any right of citation.

Nevertheless, the admitted principle would logically carry with it the right of citation for the Pope, who has aways enjoyed an independent personality in the international point of view, and who reserves a sovereignty of a spiritual order, even though his temporal power has been reduced to a minimum. But the right of citation would not appertain either to the Poles nor to the Jews, who have no longer any nationality distinct from that of the different countries of which they have become subjects, and, though it would be to our regret, we would not be able to allow it either to the Fins or to the Armenians, or to the people of Alsace-Lorraine. Nothing, however, hinders its extension to those African or Asiatic tribes who do not enjoy a personality properly speaking, because of their insufficient political organization, but whose autonomy is not to be questioned, and whose right and liberty, whenever menaced by the spirit of conquest, have no other guarantee except international law, the application of which is incumbent upon the Hague Tribunal.

Having so fixed the boundaries of the power of citation, it remains for us to show that all infractions of international law will not be less justiciable before the Hague Tribunal, however little they are able to be identified with an actual interest in the case by

10. Art. I, Sec. Io, of the American Constitution. 
one of the powers to which the right of citation belongs. Take the case of Alsace-Lorraine. It is understood that this victim of annexation will have no action nor any personal voice before the international court. But France will remain free, because of the imprescriptible character, many times proclaimed, of its claims, to introduce before the Hague Tribunal, by reason of the right of citation, which belongs to it, an action limited doubtless to its actual interest, but capable, nevertheless, of serving directly the sacred cause of the provinces which have not yet ceased to suffer because of their dismemberment. The same procedure will permit, in the same way, the bearing of the Armenian or the Finland problens before the Hague Tribunal; so that it is seen that if the door of the Supreme Tribunal remains narrow, even if it is closed except for the benefit of the nations privileged through their history, (which are too often merely the beneficiaries of usurpation or of violence), this little opening will, nevertheless, allow passage to all those currents of justice of which we expect life, so that its judgment will have penetrated elsewhere. And so the everlasting words of Gambetta will be verified. "Great reparation can result from law."

And now will an objection of opportunism be raised? Will there be a complaint that old questions will have a chance to be revived just when they were thought to be covered by oblivion? Will it be feared that in place of the wish for pacification the result of these methods will envenom the relations of friendly or contentious neighboring countries? Such apprehensions can be dispelled only by an argument of analogy. How does it work out in internal law? If the effect of the freedom of taking direct action is to cause trouble between citizens, it would probably produce an analogous inconvenience between nations as soon as they are allowed the same privilege. If, on the contrary, it is shown that free access to the Civil Tribunal, far from provoking contention among individuals, gives to each citizen a feeling of security, all this indicates that it will be the same in the international conditions. Now is it not incontrovertible that public peace within each country is forwarded as a direct result of a freedom which every person possesses, to make his appeal to social justice instead of taking justice into his own hands? Feuds, broils, personal vengeance and strikes themselves, show still and have always shown, the feebleness and insufficiency, or the incompetence of the regular courts. Violence is not used except to defend rights which no law conserves and which no institution of law protects. If questions of delicacy and honor are still solved by outbreaks or by the sword, it is because the offended parties know that their own feelings are too personal for any judge to 
appreciate them at their actual value. Professional dignity, conjugal faith, and pride are things of too inconstant weight to be measured upon the symbolic scales. That is why combats still occur to wash away disgrace in blood. But psychology, to which we now make an appeal, teaches us, on the other hand, that for all the rights which the right of citation protects, the simple fact of being able to act gives confidence to the interested parties and dissuades them from all personal action. The power to demand justice rarely stimulates anyone to bring an action. Most men never do bring an action, but all rely on the knowledge that if the necessity did arise for them there would be swift and just means to protect their rights. Public security is the result of this sentimentreasoned out by very few people, but instinctively felt by everybody.

The right of direct action will produce manifestly the same result among nations. They will not plead for the mere pleasure of pleading; they will not demand before the Hague Tribunal a recasting of the map of the world any more than individuals demand from the tribunals a redivision of property. There are certain acquired rights, the definite character of which will be admitted. That which will be prosecuted in the court, that which will be questioned, that which will be destroyed by the power of law, will be the evil of flagrant acts of injustice, the oppression of liberties and of conscience, the violation of treaties, the effusion of innocent blood, the dismemberment of countries. And who will complain at seeing finally struck down so much wickedness, which, up to now, at the mouth of a battery of cannon, has impudently defied public condemnation?

What if, nevertheless, some frivolous question, some quarrel of another age, some antiquated pretension, should be timorously carried before the Hague Tribunal? To whom rather than to it can it be entrusted to formulate in the language of law the sentence of exclusion? It is made up of men who are the wisest in the world; it is impartial and it should be sovereign. Let, then, be left to it the case of deciding, in perfect liberty and of passing judgment in each hypothesis, whether it is competent, whether it is rightfully applied to, and whether the substance of the suit really exists. The confidence which the judge deserves is in the last analysis the best argument in favor of the power of direct action.

Procureur de la République à Rethel, France.

Jacques Dumas, . 